\title{
Men and family planning in Bangladesh: A review of the literature
}

Debbie Donahoe

Follow this and additional works at: https://knowledgecommons.popcouncil.org/departments_sbsr-rh

Part of the Family, Life Course, and Society Commons, Health Communication Commons, and the International Public Health Commons

How does access to this work benefit you? Let us know!

\section{Recommended Citation}

Donahoe, Debbie. 1996. "Men and family planning in Bangladesh: A review of the literature," Asia and Near East OR/TA Project Final Report. Dhaka: Population Council. 


\section{MEN AND FAMILY PLANNING IN BANGLADESH: A REVIEW OF THE LITERATURE}

Final Report

Debbie Donahoe

The Population Council

Asia and Near East Operations Research and

Technical Assistance Project

This project was supported by the Population Council's Asia and the Near East Operations Research and Technical Assistance (ANE OR/TA) Project. The ANE OR/TA Project is funded by the US Agency for International Development, Office of Population, under Contract No.DPE-3030-C00-0022-00, Strategies for Improving Family Planning Service Delivery.

\section{Bangladesh, October 1996}




\section{EXECUTIVE SUMMARY}

This paper reviews the literature on men and family planning in Bangladesh. A variety of topics are covered: male fertility preferences, male KAP, opinions about male methods of contraception, family planning decision-making, and recent efforts to involve Bangladeshi men in family planning programs.

Men's desired family size in Bangladesh is small; only one-third of respondents in the most recent national survey, the Bangladesh Demographic and Health Survey 1993-94, wanted more than two children (Mitra et al., 1994). The same survey revealed that knowledge of at least one modern method of family planning is practically universal and that attitudes towards contraception are overwhelmingly favorable, even in the country's most conservative district, Chittagong. Religious opposition to family planning among men seems to be less common than usually thought (Bernhart and Uddin, 1990; Mazumder, 1993).

The use of vasectomy remains insignificant in Bangladesh. While considerable numbers of both men and women report unfavorable impressions of the method due to perceived side-effects (Khan, 1979; Mitra and Mitra, 1990; Islam and Rahman, 1993), observers of the national family planning program attribute the method's unpopularity largely to supply-side constraints--the emphasis on other methods and deficiencies in the availability and quality of vasectomy services (Hasan et al., 1992; Ahmed et al., 1992; Khuda, 1994). Many men also see disadvantages to condom use. Aside from the fact that buying, storing, and disposing of condoms presents men with opportunities for embarrassment, they are thought to be detrimental to one's health (Mitra and Mitra, 1990) and to be unreliable (Folmar, 1992; Khan, 1993).

Only superficial information on the frequency and quality of communication about family planning between spouses and the effects of such communication on contraceptive usage exists. Approximately 40 percent of female respondents in the DHS reported that the decision to first use a method of contraception was reached jointly with their husbands. Female-dominated decisions, though, were more frequent in those areas of the country and amongst those segments of the population where family planning is not as widely practiced (Mitra et al., 1994). While some men do not seem to communicate closely with their wives about family planning matters, other husbands are both significant sources of information about methods and suppliers of methods for their wives (Davies et al., 1987; Akhter and Ahmed, 1991).

Finally, as of yet not much effort seems to have been made to involve men in family planning programs in Bangladesh. The few references that could be found suggest (but no where near prove) that men can be successfully incorporated into outreach programs and that contraceptive prevalence can be raised through such efforts. 


\section{INTRODUCTION}

Male involvement is becoming a buzzword in the international family planning community. The term is commonly used to refer to two interrelated yet distinct programmatic goals: encouraging the use of male methods of contraception and expanding men's involvement in family planning decision-making. Basically, men are being asked to bear equal responsibility for fertility control and reproductive health. Men are getting more attention now for a variety of reasons. For one, they have been found to be more open to family planning than conventional wisdom previously held. Furthermore, recent research has also provided evidence from varied settings that supportive husbands increase the likelihood that contraceptive use is initiated and, once begun, continued. Changes have occurred in contraceptive technology as well.

Vasectomy techniques have become simpler and less costly, making male sterilization a more attractive option than in the past, both from the provider and the client standpoint. The other major male method, the condom, has been thrust into the public eye as the best method currently available to thwart the continuing spread of AIDS (MacCauley et al, 1994; Finger, 1992).

The issue is also rising to the forefront in Bangladesh. In its recent Plan of Action, the National Steering Committee for Future Challenges in the FP-MCH Program identifies eight immediate priority areas for the national family planning program. Critically undeserved groups is a focus area, and men are one of the two undeserved groups identified. While stressing the importance of involving men in family planning for the continued success of the program in Bangladesh, the NSC concluded that not enough was known about the topic to hazard any specific action plan. In response to this need, the literature review presented here attempts to gather together previous research on men and family planning in Bangladesh and to synthesize past findings with recent survey data touching on the relevant issues. In truth, not much work has been done in this area, and what we do not know is highlighted here as much as what we do know. It is hoped, though, that this literature review will be useful in finding ways to bring men into the family planning fold in Bangladesh.

\section{FERTILITY PREFERENCES}

Any discussion of men of family planning must include an exploration of male family size desires--men's fertility preferences presumably play a role in whether or not they feel a need for family planning services. The most recent available data on men's fertility desires comes from the 1993/94 Bangladesh Demographic and Health Survey (Mitra et al., 1994). The BDHS interviewed 3,248 husbands of women interviewed (ever married women aged 10-49). The following table presents the percentage of men and women wanting more children according to the number they already have.

Men's family size desires appear to be relatively small. Only one third of men report wanting more than two children and only 16 percent say that they would like more than 3 children. Comparing this data with that from the 1989 Contraceptive Prevalence Survey (not shown) reveals that fertility desires have recently decreased somewhat. The percentage of men wanting more than two children in 1989 was 39 and the percentage wanting more than 3 children was 24 (Mitra et al., 1990). While the average desired male family size is small, it is slightly larger than that of women at every parity progression with the greatest difference at the progression from 1 to 2 children. 
TABLE 1

\section{Percent of husbands and wives wanting more children according to achieved family size.}

\begin{tabular}{|c|c|c||}
\hline $\begin{array}{c}\text { Number of } \\
\text { Living Children }\end{array}$ & $\begin{array}{c}\text { Husbands } \\
\text { Wants More }\end{array}$ & $\begin{array}{c}\text { Wife Wants } \\
\text { More }\end{array}$ \\
\hline 0 & 95.3 & 91.6 \\
1 & 82.7 & 76.1 \\
2 & 33.4 & 30.7 \\
3 & 16.4 & 14.2 \\
4 & 7.5 & 5.5 \\
$5+$ & 4.1 & 1.7 \\
\hline
\end{tabular}

*adapted from Table 9.9, p.127 BDHS 1993-1994. Percent men wanting more children is the addition of husbands in the following categories: both want more, husband wants more, wife infecund and husband wants more while wife doesn't. Percent women wanting more is the addition of wives from the categories both want more and wife wants more, husband does not.

Men's family size desires appear to be relatively small. Only one third of men report wanting more than two children and only 16 percent say that they would like more than 3 children. Comparing this data with that from the 1989 Contraceptive Prevalence Survey (not shown) reveals that fertility desires have recently decreased somewhat. The percentage of men wanting more than two children in 1989 was 39 and the percentage wanting more than 3 children was 24 (Mitra et al., 1990). The average desired male family size is not only small, but is also smaller than that the average female desired family size. At each parity level, few men than women want to continue childbearing.

A more detailed picture of fertility desires emerges when one also considers men's ages and their preferred timing of fertility. The following table presents men's responses to the question of if and when they want to have more children.

TABLE 2

Percent distribution of husbands by desire for more children according to age.

\begin{tabular}{||c|c|c|c||}
\hline \hline AGE & Percent Want No More & $\begin{array}{c}\text { After } \\
\text { Two Years }\end{array}$ & Total \\
\hline $20-24$ & 11.1 & 54.4 & 65.5 \\
$25-29$ & 24.4 & 43.2 & 67.6 \\
$30-34$ & 47.2 & 26.2 & 73.4 \\
$35-39$ & 69.0 & 13.8 & 82.8 \\
$40-44$ & 81.7 & 6.3 & 88.0 \\
$45-49$ & 83.1 & 2.7 & 85.8 \\
$50-54$ & 83.9 & 0.3 & 84.2 \\
$55-59$ & 81.6 & 0.2 & 81.8 \\
$60+$ & 85.5 & 0.0 & 85.5 \\
\hline
\end{tabular}

*adapted from Table 9.8, p. 126, BDHS 1993-1994. The percent wanting no more includes those men who are sterilized. 
The data show that the percentage of men who want no more children and that want to delay the birth of the next child by at least two years increases steadily with age, with only slight jumping-around at the older ages. If one assumes that men not wanting more children are candidates for permanent methods of contraception and that men not wanting children for at least two years need temporary methods of contraception (and that those who want children within two years and aren't sure when they want kids don't need a method), then the need for family planning among Bangladeshi men is high. Over 50 percent of the men between the ages of 20 and 24 want to delay the next birth. By the ages 30 to 34, nearly one half of husbands said they wanted to stop childbearing altogether. Thus, between the ages of 20 and 30 about $3 / 5$ of men need some form of family planning to meet their fertility desires. This proportion rises to 3/4 at ages 30-34 and 4/5 at ages 35-39. Nearly 9/10 of men between 40-45 are in need family planning, most of them a permanent method. These findings suggest that if men, or couples, are not currently using contraception, it is not because of high male fertility desires.

If one knew the value of children to men, one would have a better understanding of why men desire the number they do. There is little research on this topic in Bangladesh. Some insight into this question can be gained from considering the reasons given for desiring sons. In a study conducted in both rural and urban areas of Chandpur district, Mazumder (1993) finds that men's main reasons for desiring a son are economic. ${ }^{1}$ Approximately 63 percent of urban men and 57 percent of rural men cite economic reasons--old age security and income earning potential--as the motivation to have a son. Family continuity was also an important reason to desire a son.

TABLE 3

Percentage distribution of men according to reasons for wanting sons.

\begin{tabular}{|c|c|c|}
\hline Reasons for wanting sons & $\begin{array}{l}\text { URBAN } \\
(N=192)\end{array}$ & $\begin{array}{l}\text { RURAL } \\
(\mathbf{N}=187)\end{array}$ \\
\hline Old age security & $37.2 \%$ & $30.1 \%$ \\
\hline Sons earn income & $25.6 \%$ & $26.9 \%$ \\
\hline Family continuity & $22.0 \%$ & $21.0 \%$ \\
\hline Social status & $7.9 \%$ & $11.0 \%$ \\
\hline Religious reasons & $7.3 \%$ & $10.0 \%$ \\
\hline TOTAL & $100 \%$ & $100 \%$ \\
\hline
\end{tabular}

*Mazumder (1993), p. 72. Total sample size was 380. 
Nevertheless, the usefulness of this data for understanding the issue of son preference is limited. Men are not asked, for instance, if these attributes of sons also apply to daughters or if they make boys more desirable than girls. The 1989 Contraceptive Prevalence Survey (Mitra et. al., 1990) found, though, that men were more likely to desire an end to childbearing when they had no living son or only one son than women ${ }^{2}$. Another largely unanswered question related to men's fertility desires is their perceived responsibilities to children. It isn't clear whether the small family size desires shown above are motivated more by a desire to provide for "better quality children" or because larger families simply can't be sustained in the face of hard economic times. 70 percent of respondents in the 1989 CPS said that family planning users did so to provide better education, food, and general care for their children. Only 25 percent specifically said that economic constraints necessitated family limitation (Mitra et al., 1990). Given the subtleties between curtailing childbearing because offspring are increasingly expensive to provide for and because providing for them is impossible, this area appears to require more research.

\section{KNOWLEDGE OF FAMILY PLANNING}

Whether or not Bangladeshi men are able to realize the fertility desires discussed above depends at least in part on their awareness of the means to do so. Men's knowledge of different family planning methods is presented below.

\section{TABLE 4}

Knowledge of family planning methods among married couples

\begin{tabular}{|c|c|c|c|c|c|}
\hline Method & $\begin{array}{l}\text { Percent Men } \\
\text { Knowing } \\
\text { Method }\end{array}$ & $\begin{array}{l}\text { Both Husband } \\
\text { and Wife } \\
\text { Know }\end{array}$ & $\begin{array}{l}\text { Husband Knows, } \\
\text { Wife Doesn't }\end{array}$ & $\begin{array}{l}\text { Wife Knows, } \\
\text { Husband Doesn't }\end{array}$ & $\begin{array}{l}\text { Percent Men } \\
\text { Knowing Method- } \\
1989\end{array}$ \\
\hline Any method & 99.7 & 99.6 & 0.1 & 0.3 & NA \\
\hline Any modern method & 99.7 & 99.6 & 0.1 & 0.3 & NA \\
\hline Pill & 99.2 & 98.9 & 0.3 & 0.8 & 99.0 \\
\hline IUD & 70.6 & 66.4 & 4.2 & 24.5 & 60.8 \\
\hline Injection & 90.0 & 87.6 & 2.4 & 9.3 & 82.1 \\
\hline Condom & 94.7 & 84.7 & 10.0 & 3.5 & 91.9 \\
\hline Female Sterilization & 97.7 & 96.9 & 0.8 & 2.2 & 98.9 \\
\hline Male Sterilization & 89.4 & 75.7 & 13.7 & 7.4 & 93.9 \\
\hline Any traditional method & 75.8 & 60.8 & 15.0 & 16.6 & NA \\
\hline Periodic abstinence & 68.8 & 48.2 & 20.6 & 18.3 & 48.2 \\
\hline Withdrawal & 42.2 & 25.9 & 16.3 & 25.8 & 11.8 \\
\hline Other & 10.6 & 3.6 & 7.0 & 14.4 & 40.2 \\
\hline
\end{tabular}

*adapted from Table 9.3, p. 122, BDHS 1993-1994. Sums do not add to $100 \%$ due to the omission of the category "neither knows method." The last column is taken from the Bangladesh Contraceptive Prevalence Survey - 1989 (Mitra et al., 1990).

In fact, much of what has been written about the reasons for high fertility in Bangladesh focus on why women, not men, benefit from children, especially sons. Women's economic dependence on men and the precarious balance between survival and destitution force women to seek a form of social insurance in offspring. Children may also mitigate the burden of the physical labor inherent in the household chores for which Bangladeshi women are responsible (see Mahmud's (1988) discussion of the literature). 
This table reveals a high knowledge of family planning methods among men in Bangladesh. Virtually all of the husbands sampled know of at least one modern method of contraception. Knowledge of the pill is practically universal, and knowledge of the condom and female sterilization is almost as high. Perhaps surprisingly, men are not as aware of male sterilization as they as they are of female sterilization and are also less aware of the other male methods, periodic abstinence and withdrawal, than they are of other female methods such as the IUD, and injectables. Except for withdrawal, though, men are more aware of male methods-condoms, vasectomy, and periodic abstinence--than their wives. Since 1989, there has been an increase in male knowledge of the IUD, injection, condom, periodic abstinence, and withdrawal. Though the difference is not great, fewer men in the BDHS report knowing of male sterilization than in the 1989 BCPS. Awareness of "other" methods appears to have decreased as well.

\section{APPROVAL OF FAMILY PLANNING}

The BDHS 1993-1994 asked both husbands and wives whether they approved of family planning.

\section{TABLE 5}

Percent distribution of couples by approval of family planning according to age difference between spouses and selected background characteristics, Bangladesh 1993-94.

\begin{tabular}{|c|c|c|c|c|c|c|c|c|}
\hline Background Characteristic & $\begin{array}{l}\text { Both } \\
\text { Approve }\end{array}$ & $\begin{array}{l}\text { Both } \\
\text { Disapprove }\end{array}$ & $\begin{array}{l}\text { Wife } \\
\text { Approves } \\
\text { Husband } \\
\text { Doesn't }\end{array}$ & $\begin{array}{l}\text { Husband } \\
\text { Approves } \\
\text { Wife } \\
\text { Doesn't }\end{array}$ & Missing & Total & $\begin{array}{l}\text { Percent } \\
\text { Who } \\
\text { Agree }\end{array}$ & $\begin{array}{l}\text { Number of } \\
\text { Couples }\end{array}$ \\
\hline $\begin{array}{l}\text { Age difference } \\
\text { Wife Older } \\
0-4 \\
5-9 \\
10-14 \\
15+\end{array}$ & $\begin{array}{l}(84.2) \\
90.2 \\
89.7 \\
89.0 \\
84.3\end{array}$ & $\begin{array}{l}(0.0) \\
0.8 \\
1.7 \\
0.8 \\
3.3\end{array}$ & $\begin{array}{l}(10.5) \\
5.5 \\
5.8 \\
5.7 \\
7.5\end{array}$ & $\begin{array}{l}(5.3) \\
3.5 \\
2.6 \\
4.2 \\
4.1\end{array}$ & $\begin{array}{l}0.0 \\
0.0 \\
0.3 \\
0.3 \\
0.8\end{array}$ & $\begin{array}{l}100.0 \\
100.0 \\
100.0 \\
100.0 \\
100.0\end{array}$ & $\begin{array}{l}(84.2) \\
91.0 \\
91.4 \\
89.8 \\
87.6\end{array}$ & $\begin{array}{c}44 \\
473 \\
1338 \\
938 \\
534\end{array}$ \\
\hline $\begin{array}{l}\text { Residence } \\
\text { Urban } \\
\text { Rural }\end{array}$ & $\begin{array}{l}94.7 \\
87.8\end{array}$ & $\begin{array}{l}0.1 \\
1.7\end{array}$ & $\begin{array}{l}3.2 \\
6.4\end{array}$ & $\begin{array}{l}1.4 \\
3.7\end{array}$ & $\begin{array}{l}0.7 \\
0.3\end{array}$ & $\begin{array}{c}100.0 \\
100.0\end{array}$ & $\begin{array}{l}94.8 \\
89.6\end{array}$ & $\begin{array}{c}384 \\
2942\end{array}$ \\
\hline $\begin{array}{l}\text { Division } \\
\text { Barisal } \\
\text { Chittagong } \\
\text { Dhaka } \\
\text { Khulna } \\
\text { Rajshahi }\end{array}$ & $\begin{array}{l}92.8 \\
79.3 \\
89.9 \\
90.1 \\
93.5\end{array}$ & $\begin{array}{l}1.4 \\
4.3 \\
0.8 \\
0.9 \\
0.3\end{array}$ & $\begin{array}{l}2.9 \\
9.9 \\
5.7 \\
6.3 \\
3.7\end{array}$ & $\begin{array}{l}2.9 \\
6.2 \\
3.2 \\
2.2 \\
2.1\end{array}$ & $\begin{array}{l}0.0 \\
0.2 \\
0.3 \\
0.5 \\
0.4\end{array}$ & $\begin{array}{l}100.0 \\
100.0 \\
100.0 \\
100.0 \\
100.0\end{array}$ & $\begin{array}{l}94.2 \\
83.6 \\
90.7 \\
91.0 \\
93.8\end{array}$ & $\begin{array}{c}209 \\
757 \\
1047 \\
447 \\
872\end{array}$ \\
\hline $\begin{array}{l}\text { Couple's Education } \\
\text { Both none } \\
\text { Wife some/husband none } \\
\text { Husband some/wife none } \\
\text { Both some }\end{array}$ & $\begin{array}{l}93.9 \\
89.2 \\
85.7 \\
85.6\end{array}$ & $\begin{array}{l}0.7 \\
1.9 \\
1.3 \\
2.4\end{array}$ & $\begin{array}{l}3.5 \\
5.8 \\
7.7 \\
7.4\end{array}$ & $\begin{array}{l}1.8 \\
2.3 \\
4.5 \\
4.5\end{array}$ & $\begin{array}{l}0.1 \\
0.8 \\
0.7 \\
0.1\end{array}$ & $\begin{array}{l}100.0 \\
100.0 \\
100.0 \\
100.0\end{array}$ & $\begin{array}{l}94.7 \\
91.1 \\
87.0 \\
88.0\end{array}$ & $\begin{array}{c}1078 \\
292 \\
845 \\
1113\end{array}$ \\
\hline TOTAL & 88.6 & 1.5 & 6.1 & 3.4 & 0.3 & 100.0 & 90.2 & 3327 \\
\hline
\end{tabular}

Note: Figures in parentheses are based on 25 to 49 cases

* from Bangladesh Demographic and Health Survey 1993-94, p. 125 (Mitra et al., 1994).

According to this table, 92 percent of husbands interviewed said that they approved of family planning, which is slightly less than the percentage of women who expressed 
approval. More urban men than rural men, 96.1 percent versus 91.5 percent respectively, say they support family planning. There is little variation in approval ratings between the divisions of Bangladesh, with the exception of Chittigong, in which only 85.5 percent of husbands approve. The most striking thing here is the widespread approval men report for family planning. Even in the most conservative area of the country, only 15 percent of the men interviewed expressed disapproval.

Some explanation for the belief that men stand in the way of contraceptive use is available from the paired responses to the question of spouse's approval of family planning.

\section{TABLE 6}

Percent distribution of couples by husband's and wife's attitude towards family planning, according to their spouse's perception of their attitude, Bangladesh 1993-94

\begin{tabular}{|c|c|c|c|c|c|}
\hline \multirow{2}{*}{$\begin{array}{c}\text { Wife's } \\
\text { Perception }\end{array}$} & \multicolumn{3}{|c|}{ Husband } & \multirow{2}{*}{ TOTAL } & \multirow{2}{*}{$\begin{array}{c}\text { Number of } \\
\text { Couples }\end{array}$} \\
\hline & Approves & Disapproves & Unsure & & \\
\hline $\begin{array}{l}\text { Believes approves } \\
\text { Believes disapproves } \\
\text { Doesn't Know }\end{array}$ & $\begin{array}{l}96.5 \\
78.4 \\
88.2\end{array}$ & $\begin{array}{c}3.3 \\
21.6 \\
11.8\end{array}$ & $\begin{array}{l}0.2 \\
0.0 \\
0.0\end{array}$ & $\begin{array}{l}100.0 \\
100.0 \\
100.0\end{array}$ & $\begin{array}{c}2879 \\
189 \\
259\end{array}$ \\
\hline TOTAL & 94.8 & 5.0 & 0.2 & 100.0 & 3327 \\
\hline \multirow[t]{2}{*}{$\begin{array}{l}\text { Husband's } \\
\text { perception }\end{array}$} & \multicolumn{3}{|c|}{ Wife } & \multirow[t]{2}{*}{ TOTAL } & \multirow[t]{2}{*}{$\begin{array}{c}\text { Number of } \\
\text { Couples }\end{array}$} \\
\hline & Approves & Disapproves & Unsure & & \\
\hline $\begin{array}{l}\text { Believes approves } \\
\text { Believes disapproves } \\
\text { Doesn't know }\end{array}$ & $\begin{array}{l}95.2 \\
69.8 \\
89.1 \\
\end{array}$ & $\begin{array}{r}4.7 \\
29.5 \\
10.9 \\
\end{array}$ & $\begin{array}{l}0.1 \\
0.7 \\
0.0\end{array}$ & $\begin{array}{l}100.0 \\
100.0 \\
100.0\end{array}$ & $\begin{array}{c}2788 \\
343 \\
196 \\
\end{array}$ \\
\hline TOTAL & 92.2 & 7.6 & 0.2 & 100.0 & 3327 \\
\hline
\end{tabular}

*from Bangladesh demographic and Health Survey 1993-94. p. 125 (Mitra et el.,1994).

Most women report that their husbands approve of family planning. Only 5.7 percent of wives nationwide believe that their husbands do not approve, and another 7.8 percent say that they do not know their husbands' opinions. But, the vast majority of men, 78.4 percent, whose wives think they do not approve of family planning actually do approve. And, furthermore, 88.2 percent of men whose wives do not know their opinion approve as well. Assuming that men are responding truthfully, couples are not communicating correctly or, in the absence of any communication, women are just presuming that their husbands do not approve. Alternatively, men may be giving interviewers the answer they think is wanted. 
That women often report disapproval that their husbands do not themselves profess has been found in previous research. Bernhart and Uddin (1990) interviewed husbands whose wives had reported them to be opposed to family planning on the basis of their religious beliefs (14.6 percent of the sampled women said their husbands had religious-based opposition to family planning). Surprisingly, 26 percent of these supposed opposers reported that the couple was currently using contraception (their wives had reported no use). In addition, 57.5 percent of the "opposers" interviewed approved of family planning for child spacing and 50 percent approved of use for limiting family size. The authors propose that the high incidence of false reporting could be due to women's reluctance to tell their true reasons for not practicing family planning. Blaming their husbands' religious beliefs may offer them a socially acceptable scapegoat.

The strength of men's religious opposition to family planning appears to be overstated as well. In the same study, only 22.6 percent of men reported as having religious opposition to family planning actually did oppose the use of contraception on the basis of Islamic beliefs. Therefore, only 3.5 percent of the husbands in the sample opposed family planning on religious grounds, and the vast majority of these men could give only vague reasons why their religion forbids family planning ${ }^{3}$. That religious opposition to family planning is generally not based on specific knowledge of the tenets of Islam was also found by Mazumder (1993) in Chandpur district. While the actual level of opposition may not be high, the perception that the level is high, or that it is a social plus to oppose family planning, means that policy makers can not dismiss this potential threat to family planning acceptance.

\section{MALE METHODS OF CONTRACEPTION}

Increasing the use of male methods of contraception is probably the most obvious way of getting men more involved with family planning. Over time, though, the percentage of contracepting couples using modern male methods, the condom and vasectomy, has declined. Figure 1 shows the trend in method mix in Bangladesh from 1975 to 1993 . Relative condom use has dropped from 14.6 to 8.2 percent while vasectomy use has gone from 10.4 to 3.0 percent. The consensus is that the drop in male sterilizations has been due mainly to supply side factors. The expansion of the community-based distribution system offering a variety of methods, the abolition of quotas for sterilizations, the abolition of payments to referrers and FWAs, the erosion of the quality of medical services and shortages in trained providers (which discourages FWAs from referring clients), and the decrease in value, due to inflation, of the 175 Taka payment for sterilization are offered as programmatic reasons for the decline (Hasan et al., 1992; Ahmed et al., 1992; e-Khuda, 1994). While programmatic changes may also be necessary, any efforts to reverse the trend in male method use must be based on an understanding of men's (and women's) attitudes towards the condom and vasectomy.

Only men said to oppose family planning for religious reasons were interviewed in this study. Women who reported that their husbands were against family planning for other reasons $(7.4 \%$ of the $22 \%$ husbands cited as opposing) were excluded. It should also be noted that this survey was intentionally situated in a religiously conservative are of the country--Lakshimpur. 


\section{THE CONDOM}

While awareness of the condom has increased, there has also been an increase the percentage of both men and women with negative impressions of the method. The Followup Survey of Contraceptive Knowledge and Information Study (Mitra and Mitra, 1990) asked those respondents who were aware of condoms whether they could be harmful to one's health. While the majority said that condoms were not health hazards (ranging from 60 percent for rural females to 74 percent for urban males), a decreasing trend is notable. Between 1987 and 1990 the percent of respondents stating that condoms were not health hazards fell over all categories of respondents. The data, though, provides no basis on which to propose hypotheses for this development. Health concerns were stronger in rural areas and more women than men, in both urban and rural areas, believe that condoms can cause side effects. Commonly mentioned effects of condom use by those citing health concerns include physical weakness and deteriorating health, sores in the vagina, and sores on the penis. When asked where they learned about the detrimental effects of condoms, respondents reported from friends, relatives, neighbors and personal experience (Mitra and Mitra, 1990).

The perception that condoms are not reliable is common as well. Folmar's (1992) condom study found that 40 percent of the sampled users reported having a condom break. It is also one of the major reasons people give for not intending to use condoms in the future (Mitra and Mitra, 1990). Market research has found that only half those surveyed agreed with statement that "condoms don't leak or burst" (Khan, 1993).

Folmar's (1992) qualitative work on condoms revealed that there is still a significant amount of embarrassment surrounding condom use, partly because a condom is associated with a specific act of coitus. Because of this embarrassment, men typically buy condoms in such a way as to decrease the chance that his purchase will be known to his peers: at night, outside of his neighborhood, in large quantities, so as to minimize the number of times purchases are made, as part of a list of innocuous items, to camouflage the purchase, and without specifying a brand, to minimize discussion. Another problem with condoms is their storage. People do not want others, like children, to be aware that they are in the house, yet hiding places are scarce in the typical home. Discarding condoms is also a problem for users. Furthermore, men complain of the smell of condoms and that they are uncomfortable and difficult to use (Folmar et al., 1992). Women express some reluctance to use condoms as they inhibit their husbands' sexual pleasure (Mitra and Mitra, 1990; Folmar et al., 1992).

Users of condoms, not surprisingly, take a slightly different view of the method. Users report liking condoms because they are used according to their own convenience, because of an absence of side effects, because they are safe and easy to use, inexpensive, and readily available (Mitra and Mitra, 1990; Folmar et al., 1992).

Of certain importance for increasing the use of condoms is the finding that users lack information on correct condom use. At the time of Folmar's field research, instructions for use were not included on condom packages, and FWAs reported discomfort in discussing their use. As a result, condoms are misused in a variety of way: using two condoms at once, one on top of the other (because of fears of breakage), using condoms with the withdrawal method as an attempt to maximize sexual pleasure (which is the most common misuse), using them during a woman's 
safe period without adequate knowledge of the menstrual cycle; unrolling condoms before putting them on; and using a single condom more than once (Folmar et al., 1992).

\section{VASECTOMY}

Bangladeshis also express concerns about the potential health effects of vasectomy. The Followup Survey of Contraceptive Knowledge and Information, 1990 (Mitra and Mitra, 1990) found that health concerns about male sterilization were higher in rural areas. The percentage of people saying that sterilization could be harmful to one's health varied between 20.4 percent for urban males to 37.7 percent for rural males. Rural females had less concern for the health effects of vasectomy than rural males (34.7 percent), while urban females had more concern than corresponding males (30.6 percent). Physical weakness, loss of strength and a general deterioration of health were the most commonly perceived negative health effects of vasectomy. If fact, the majority of respondents in 1990 professed to "dislike" vasectomy--60.0 percent of rural males, 71.1 percent of rural females, 43.1 percent of urban males, and 65.3 percent of urban females. Except for urban males, a higher percentage of people disliked vasectomy in 1990 than in $1987^{4}$. On the other hand, the main reason given for liking sterilization is that it is an effective method.

Studies of vasectomized men provide another way to look at the acceptability of the method. There have been several studies of satisfaction among users. Over time, the percentage of vasectomy clients reporting satisfaction with the method appears to have increased. Earlier studies found 50 percent or less of users to be satisfied (Khan et al., 1979; Swenson and Khan, 1982). Perceived health problems played a major role in dissatisfaction. There is some suggestion, though, that symptoms like weakness are incorrectly attributed to vasectomy: 58 percent of matched nonvasectomized controls also felt a decreased ability to work in the past year (Khan et al., 1979). A more recent study of client satisfaction paints a different picture. To answer the question of whether dissatisfaction among already sterilized men played a role in the fall in sterilizations performed, Islam and Rahman (1993) interviewed 1600 men from both rural and urban areas in the summer of 1990. They found that satisfaction depended on a man's past experience with contraception. While 93 percent of vasectomy clients who had previously used contraception were satisfied; only 3.9 percent of those who had never used before were satisfied. But, these men were not "dissatisfied"--92.2 percent of previous nonusers said they were neither satisfied nor regretted their vasectomy. Again, the main reasons for regret were illness and deterioration of health. Those men who were satisfied said it was because their wives would have no more children (Islam and Rahman, 1993).

\section{SOURCES OF INFORMATION AND DECISION MAKING: MALE METHODS}

There are a number of important questions related to decision making that must be answered before effective efforts to increase male involvement in family planning can be undertaken. Perhaps the most basic question is where do men get information

4 In $1990,61 \%$ of rural males, $71 \%$ of rural females, $43 \%$ of urban males, and $65 \%$ of urban females who were aware of vasectomy said they "disliked" it. 
about family planning? When current users of condoms were asked where they first heard of condoms, they cited the radio, government workers and television as the most important sources of information. 58.6 percent of the current users first heard about condoms from the radio and 18.6 percent from government field workers. Informal networks did not appear to be a significant source of information, though, as 70 percent reported that they have not discussed the use of condoms with others. When they did, it was with friends and family, first, and doctors and fieldworkers second (Folmar, 1992). While there is not much research about where men get information, there is even less about who or what are important forces in the formation of opinions about family planning. For instance, the relative importance of friends, family members, family planning workers, and opinion leaders is not known. Bernhart and Uddin (1990) found that men who were religiously opposed to family planning sometimes mentioned a local religious leader as the source of their information. The success of family planning projects which have included men and opinion leaders, both traditional and religious leaders, in discussions about family planning (Jiggasha, Save the Children ${ }^{5}$ ) suggests that these people may be important influences on men.

Another significant, related topic is how men make decisions to adopt a method. Much of the work done on male decision-making had focused on vasectomy and is motivated by concerns over the role of incentive payments--to clients, providers and referrers--in decisions. At the heart of the matter is whether or not men are making informed decisions based on a motivation to stop childbearing. While it appears that the decision to undergo vasectomy is voluntary and that compensation payments are not a primary motivator, they may contribute to the decision in a large majority of cases (Alauddin et al, 1988; Cleland and Mauldin, 1991). Nonetheless, there is evidence that at least the timing of a vasectomy may be based upon an impending economic crisis even though the respondent may have been considering the operation for some time (Alauddin et al. 1988) ${ }^{6}$. Vasectomy clients consult a number of different people before submitting to the procedure--friends and relatives, other villagers, and other users of the method (Cleland and Mauldin, 1991). Alaaudin et al.'s (1988) interviews with vasectomized men found that FWV's, FWA's, doctors, and vasectomy referrers were also consulted. Swenson and Khan's (1982) follow-up study of vasectomy and tubectomy clients found that men never mentioned their wives as the most influential person in their decision to have a vasectomy, rarely mentioned other family members, and mentioned themselves in less than $1 / 2$ of cases, which seems to point to the importance of vasectomy recruiters when payments to referrers was a feature of the program. Another interesting sidelight on vasectomy decision making is that vasectomy clients tend to be less knowledgeable about family planning than the general public and to have little or no prior use of methods (Swenson and Khan, 1982; Alauddin et al., 1988). The decision to have a vasectomy, therefore, does not appear to be part of a transition from temporary to permanent contraceptive methods. The extent to which the decision-making processes of vasectomy clients can be generalized to other methods, therefore, is questionable.

These programs are discussed later.

6 The published reports includes 8 interviews with vasectomy acceptors. While this small sample of this study makes one wary to generalize, the common themes that emerged are generally supported by other research. 


\section{HUSBAND-WIFE COMMUNICATION}

Male involvement, of course, does not only refer to male methods. It includes supporting the use of female methods as well, which implies that husbands must communicate with their wives about family planning. Interspousal communication, for example, has been found to be predictive of contraceptive use (Chaudhury, 1978; De Jong et al., 1989) and of better knowledge of proper pill use (Davies, 1985) in Bangladesh. Traditionally, though, communicating about matters related to fertility and family planning is not the norm (Abdullah and Zeidenstein as quoted in Kincaid, 1993), and couples desiring to do so may be hampered by lack of privacy. If discussion does occur, it is not at the onset of a marriage, but after a significant period of time has passed, somewhere between five to ten years (Aziz and Maloney, 1985). Barriers to communication can be broken down, though. Jiggasha meetings (community meetings where FWAs facilitate the discussion of family planning) appear to encourage women to broach family planning with their husbands by giving them the opportunity to first discuss the subject with members of their own sex, raising their confidence and ability to broach a sensitive topic (MacCauley, 1994).

Although the BDHS asked women if they had talked to their husbands about family planning, the results are not available yet. Inferences about communication can be made from less direct information, though. 


\section{Table 7}

Percent distribution of couples according to wife's and husband's reported current contraceptive use status, Bangladesh 1993-94

\begin{tabular}{|c|c|c|c|c|c|c|c|c|c|c|c|}
\hline \multirow{2}{*}{ Husband's Report } & \multicolumn{10}{|c|}{ Wife's Report } & \multirow{2}{*}{ Total } \\
\hline & Pill & IUD & Injection & Condom & $\begin{array}{c}\text { Female } \\
\text { Sterilization }\end{array}$ & $\begin{array}{c}\text { Male } \\
\text { Sterilization }\end{array}$ & $\begin{array}{l}\text { Periodic } \\
\text { Abstinenc } \\
\text { e }\end{array}$ & Withdrawal & Other & $\begin{array}{c}\text { Not Currently } \\
\text { Using }\end{array}$ & \\
\hline Pill & 16.9 & 0.2 & 0.6 & 0.1 & 0.0 & 0.0 & 0.7 & 0.3 & 0.1 & 3.8 & 22.8 \\
\hline IUD & 0.0 & 1.8 & 0.0 & 0.0 & 0.0 & 0.0 & 0.1 & 0.0 & 0.0 & 0.1 & 2.0 \\
\hline Injection & 0.2 & 0.0 & 3.7 & 0.0 & 0.0 & 0.0 & 0.1 & 0.0 & 0.0 & 0.6 & 4.6 \\
\hline Condom & 0.1 & 0.0 & 0.0 & 2.3 & 0.0 & 0.0 & 0.3 & 0.2 & 0.0 & 1.0 & 4.0 \\
\hline Female Sterilization & 0.0 & 0.0 & 0.0 & 0.0 & 8.1 & 0.1 & 0.0 & 0.0 & 0.0 & 0.4 & 8.6 \\
\hline Male Sterilization & 0.1 & 0.0 & 0.0 & 0.0 & 0.3 & 1.3 & 0.1 & 0.0 & 0.0 & 0.4 & 2.2 \\
\hline Periodic Abstinence & 0.2 & 0.1 & 0.1 & 0.2 & 0.1 & 0.0 & 2.2 & 0.7 & 0.1 & 4.2 & 7.8 \\
\hline Withdrawal & 0.1 & 0.0 & 0.0 & 0.0 & 0.0 & 0.0 & 0.4 & 1.0 & 0.1 & 0.6 & 2.1 \\
\hline Other & 0.1 & 0.0 & 0.0 & 0.0 & 0.0 & 0.0 & 0.1 & 0.0 & 0.6 & 0.5 & 1.3 \\
\hline Not Currently Using & 0.9 & 0.3 & 0.4 & 0.4 & 0.1 & 0.0 & 1.9 & 0.9 & 0.5 & 39.3 & 44.6 \\
\hline TOTAL & 18.6 & 2.3 & 4.8 & 3.0 & 8.6 & 1.4 & 5.8 & 3.1 & 1.4 & 50.9 & 100.0 \\
\hline
\end{tabular}

*From Bangladesh demographic and Health survey 1993-94, p. 124 (Mitra et al., 1994) 
This table matches husband and wife reports of current contraceptive use status. It reveals a considerable amount of discrepancy--23 percent of couple's responses do not match. Men report more current use across all methods than women, 55.4 percent vs. 49.1 percent respectively. The greatest source of this discrepancy occurs in pill use reporting. Men report more pill use than women, most of the difference coming from women who report that they are not using any method. Perhaps men are not aware of recent discontinuations and are reporting a past use-status. The other major source of discrepancy is the reporting of periodic abstinence ${ }^{7}$. There is more disagreement between husbands and wives than agreement for this method, with the greatest percentage of reports of use coming from husbands whose wives say they are using no method. The 1989 Contraceptive Prevalence Survey also found the reporting of safe period usage to be a source of significant disagreement between spouses. It was postulated that couples practicing the safe period method were likely to give different answers because they were the most uncomfortable discussing family planning together (Mitra et al., 1990). Whatever the cause of this reporting gap, it serves as evidence that it is not uncommon for husband-wife communication to be so limited as to prevent them from having a common understanding of their contraceptive status.

Other pieces of information paint a different picture, though. Some husbands serve as sources of information and suppliers of methods for their wives, implying that they must communicate to some degree about family planning. The Contraceptive Use Dynamics (CUD) ${ }^{8}$ study (Akhter and Ahmed, 1991) asked women who was their initial and major source of information about contraception. The results are presented below.

TABLE 8

Percent of current users citing their husbands as the initial and major source of information about contraceptive methods by method.

\begin{tabular}{||l|l|l||}
\hline & Initial Source & Major Source \\
\hline Pill & $15.2 \%$ & $23 \%$ \\
\hline IUD & $8.7 \%$ & $4.3 \%$ \\
\hline Condom & $35.9 \%$ & $43.6 \%$ \\
\hline Injection & $26.7 \%$ & $33.3 \%$ \\
\hline Tubectomy & $19.4 \%$ & $20.8 \%$ \\
\hline Vasectomy & $28.6 \%$ & $14.3 \%$ \\
\hline Traditional & $28.1 \%$ & $29.2 \%$ \\
\hline TOTAL & $\mathbf{1 9 . 5 \%}$ & $\mathbf{2 3 . 9 \%}$ \\
\hline
\end{tabular}

*adapted from Akhter and Ahmed (1991), tables 5.1 and 5.2, p.37-38.)

Over all methods, a total of 19.5 percent of women said they first heard of family planning from their husbands. An even greater number, 24 percent, said that their husbands were their

7 Because there are fewer users of periodic abstinence than the pill, though the raw number of disagreeing couples is smaller, the proportion disagreeing is actually higher for this method than the pill.

8 The CUD is a 1988 survey based on 1985 CPS sampling frame excluding urban women, women not currently married, women sterilized before 1985, and women with no living children in at time of CPS. 
major source of information. In both cases, the percent is highest for condom. Users of social marketing brands of oral contraceptives are generally dependent upon their husbands not only for information about pill use but for the purchase of supplies as well (Davies et al., 1987). The importance of husbands as providers depends, though, on the proportions of usercouples obtaining supplies from the commercial sector. The 1993/94 BDHS shows that 70 percent of women get their supplies from FWAs. Another 5.1 percent get their pills from other public outlets (government hospital, FWV, Thana health complex, and satellite clinic). Presumably, husbands play a major role as providers in the remaining cases. One issue raised by this finding is whether husbands provide correct information on oral pill use to their wives and where they themselves get information on the method (Davies et al., 1987).

\section{HUSBAND-WIFE DECISION-MAKING}

Perhaps of even greater interest than whether men talk to their wives about family planning is the weight of their opinions on any decisions made. Again, the evidence is mixed, and no firm conclusion on who has more decision-making power can be drawn. The most recent data again comes from the BDHS.

Women who had ever used family planning were asked who had more influence in the first decision to use a method. Overall, 40 percent of women, more than any other category, report that the decision was reached jointly. The percentage of women saying that they had the most influence (30 percent) is higher than the percent saying that their husbands were the dominant decision-maker (22 percent). This pattern is not consistent throughout the population of ever-users, though. Stratifying this population by age reveals that while the percentage reporting a joint decision remains fairly constant throughout the age groups (except in the small sample of 10-14 year-olds), women under 25 are more likely to report their husbands as the most influential and older women more likely to say that they were the most influential. There are several possible interpretations of this finding. First, it is possible that women gain more decision making power with age. But, since it is not known how long ago these older women first adopted contraception, it is also possible that women took more independent decision with regard to family planning in the past than in the present. It could be that when family planning was not a common practice, only the most innovative, independent women became users. An alternative explanation could be that older women are more susceptible to memory recall error than younger women.

Only when stratifying the population by age does the percentage of women reporting that their husbands were the dominant decision maker vary from the average. When one compares by urban/rural residence, by division, or by education, the percentage of maledominated decisions remains constant and differences are seen only in shifts from joint decision-making to female-dominated decisions. For instance, in Rajshahi, joint decisionmaking is 8 percentage points higher than the national average and female-dominated decisions are 5 percentage points lower than the average. In Chittigong, an opposite patterns prevails. Joint decision-making is 5 percentage points lower than the average and femaledominated decisions are 5 percentage points higher. This is an interesting pattern in light of the fact that Chittigong Division has the lowest CPR in Bangladesh (29.3 percent) and is 


\section{Table 9}

Percent distribution of ever-married women who have ever used modern family planning by whether respondent or her husband had more influence in the decision to first use family planning, according to selected background characteristics, Bangladesh 1993-94.

\begin{tabular}{|c|c|c|c|c|c|c|c|c|}
\hline $\begin{array}{l}\text { Background } \\
\text { Characteristic }\end{array}$ & $\begin{array}{r}\text { Respondent Had } \\
\text { More Influence }\end{array}$ & $\begin{array}{l}\text { Husband Had } \\
\text { More Influence }\end{array}$ & $\begin{array}{l}\text { Husband and Wife } \\
\text { Had Equal Influence }\end{array}$ & $\begin{array}{l}\text { Other Relative Had } \\
\text { More Influence }\end{array}$ & Other & $\begin{array}{c}\text { Not } \\
\text { Stated/Missing }\end{array}$ & Total & $\begin{array}{l}\text { Number } \\
\text { of Women }\end{array}$ \\
\hline $\begin{array}{l}\text { AGE } \\
10-14 \\
15-19 \\
20-24 \\
25-29 \\
30-34 \\
35-39 \\
40-44 \\
45-49\end{array}$ & $\begin{array}{c}9.8 \\
19.4 \\
25.7 \\
29.7 \\
32.5 \\
35.2 \\
32.3 \\
35.9\end{array}$ & $\begin{array}{l}59.3 \\
34.2 \\
25.8 \\
19.9 \\
20.5 \\
16.6 \\
17.8 \\
17.2\end{array}$ & $\begin{array}{l}16.3 \\
39.9 \\
42.5 \\
43.4 \\
38.6 \\
39.7 \\
39.0 \\
36.3\end{array}$ & $\begin{array}{l}8.2 \\
3.2 \\
2.4 \\
1.9 \\
1.3 \\
1.9 \\
2.1 \\
4.5\end{array}$ & $\begin{array}{l}0.0 \\
1.1 \\
0.6 \\
1.0 \\
0.4 \\
0.9 \\
1.2 \\
1.5\end{array}$ & $\begin{array}{l}6.4 \\
2.3 \\
3.1 \\
4.1 \\
6.6 \\
5.6 \\
7.6 \\
4.5\end{array}$ & $\begin{array}{l}100.0 \\
100.0 \\
100.0 \\
100.0 \\
100.0 \\
100.0 \\
100.0 \\
100.0\end{array}$ & $\begin{array}{c}33 \\
448 \\
1159 \\
1353 \\
979 \\
790 \\
452 \\
228\end{array}$ \\
\hline $\begin{array}{l}\text { Residence } \\
\text { Urban } \\
\text { Rural }\end{array}$ & $\begin{array}{l}29.2 \\
29.7\end{array}$ & $\begin{array}{l}18.6 \\
22.5\end{array}$ & $\begin{array}{l}43.6 \\
40.2\end{array}$ & $\begin{array}{l}1.4 \\
2.3\end{array}$ & $\begin{array}{l}0.7 \\
0.9\end{array}$ & $\begin{array}{l}6.5 \\
4.4\end{array}$ & $\begin{array}{l}100.0 \\
100.0\end{array}$ & $\begin{array}{r}787 \\
4654\end{array}$ \\
\hline $\begin{array}{l}\text { Division } \\
\text { Barisal } \\
\text { Chittagong } \\
\text { Dhaka } \\
\text { Khulna } \\
\text { Rajshahi }\end{array}$ & $\begin{array}{l}30.7 \\
35.3 \\
30.7 \\
29.3 \\
24.5\end{array}$ & $\begin{array}{l}22.2 \\
21.8 \\
21.5 \\
23.3 \\
21.7\end{array}$ & $\begin{array}{l}40.1 \\
35.5 \\
38.8 \\
37.6 \\
48.5\end{array}$ & $\begin{array}{l}1.9 \\
2.0 \\
3.2 \\
1.5 \\
1.4\end{array}$ & $\begin{array}{l}0.4 \\
1.4 \\
1.2 \\
0.7 \\
0.2\end{array}$ & $\begin{array}{l}4.7 \\
4.0 \\
4.7 \\
7.7 \\
3.7\end{array}$ & $\begin{array}{l}100.0 \\
100.0 \\
100.0 \\
100.0 \\
100.0\end{array}$ & $\begin{array}{r}374 \\
1028 \\
1755 \\
811 \\
1473\end{array}$ \\
\hline $\begin{array}{l}\text { Education } \\
\text { No Education } \\
\text { Primary Incomplete } \\
\text { Primary Complete } \\
\text { Secondary/Higher }\end{array}$ & $\begin{array}{l}33.9 \\
29.7 \\
26.8 \\
19.9\end{array}$ & $\begin{array}{l}21.0 \\
23.0 \\
23.2 \\
22.7\end{array}$ & $\begin{array}{l}37.6 \\
40.4 \\
42.4 \\
48.2\end{array}$ & $\begin{array}{l}2.7 \\
1.9 \\
1.2 \\
1.4\end{array}$ & $\begin{array}{l}1.1 \\
0.9 \\
1.0 \\
0.1\end{array}$ & $\begin{array}{l}3.7 \\
4.2 \\
5.4 \\
7.7\end{array}$ & $\begin{array}{l}100.0 \\
100.0 \\
100.0 \\
100.0\end{array}$ & $\begin{array}{r}2803 \\
1018 \\
564 \\
1957\end{array}$ \\
\hline TOTAL & 29.7 & 21.9 & 40.7 & 2.2 & 0.8 & 4.7 & 100.0 & 5442 \\
\hline
\end{tabular}

* from Bangladesh Demographic and Health Survey 1993-94, p.50 (Mitra et al., 1994) 
generally considered the most conservative are of the country and Rajshahi, along with Khulna, has the highest CPR (54.8 percent) and is a more progressive area (Table 4.9, p. 49, BDHS). This pattern suggests that in the low-performing area of Chittigong, where the adoption of contraception is still an innovative idea, women are more likely to be acting on their own. In areas where use is high, couples tend to make joint decisions. Although it isn't clear whether living in an area where approval of family planning is high encourages men to become involved in the decision-making process or whether their involvement itself contributes to high prevalence (or whether the relationship is spurious), the possibility of a relationship between the two factors deserves further attention.

A similar type of pattern is evident when the sample of female ever-users is stratified by education. Women with higher education, a group which uses family planning at a higher rate than other women, are more likely to have made the decision to first use contraception jointly with their husbands than women with low education, 48.2 versus 37.6 percent respectively. Again, an association between joint decision-making and the acceptance of family planning is something to be investigated further.

Male education level also has significance for decision making. Whether or not a man actually dominates decisions, the level of his education is predictive of the degree to which he thinks decision-making should be his sole prerogative. In Chandpur, the percent of men thinking that they should make the decision regarding family planning is 62.4 percent for the uneducated, 60.0 for those with less than 5 years of schooling, 34.5 for those with 5-10 years of schooling, and 22.6 for men educated 10 or more years (Mazumder, 1993).

The extent to which husbands hold sway in decisions seems to also vary according to method. When asked what was the main reason they decided to use the method they are currently using, the percentage of women saying that their "husbands preferred" that method varied as follows:

\section{Table 10}

\section{Percent of current users of family planning who decided to use the method due to husbands' preference.}

\begin{tabular}{||c|c|l|c|l|l|l|l|c|c||}
\hline Pill & IUD & $\begin{array}{l}\text { Injec } \\
\text { tion }\end{array}$ & Condom & $\begin{array}{l}\text { Tubect } \\
\text { omy }\end{array}$ & $\begin{array}{l}\text { Vasct } \\
\text { omy }\end{array}$ & $\begin{array}{l}\text { Absti } \\
\text { nence }\end{array}$ & $\begin{array}{l}\text { With } \\
\text { drawal }\end{array}$ & Other & Total \\
\hline 10.4 & 6.0 & 5.5 & $\mathbf{1 8 . 6}$ & 8.5 & $\mathbf{3 6 . 6}$ & $\mathbf{1 3 . 5}$ & $\mathbf{2 7 . 0}$ & 8.9 & 11.7 \\
\hline
\end{tabular}

*adapted from table 4.13, p. 52, BDHS 1993-94

Men do not often play the major role in choosing between methods. But, not surprisingly, the table suggests that men are more involved in the decision to use male methods than they are in non-male dependent methods. When men are the primary decision makers, they appear to choose methods whose use is totally or primarily their responsibility.

Another potentially important variable in the decision-making process is the source of methods. In Folmar's (1992) condom use study, some men reported encouragement from their wives to use condoms, especially if the supplies were received from government fieldworkers. This 
suggests that women may play a larger role in decisions when they are the receiver of supplies and information.

\section{PROGRAM EFFORTS TO REACH MEN}

Men have generally been neglected by family planning programs. There have been several attempts made, though, to include men in efforts to increase contraceptive prevalency. One such program is the Rural Communication Program (RCP) of Johns Hopkins University/Center for Communication Programs and the IEM Unit of the Directorate of Family Planning, MOHFW. RCP features the "Jiggasha Approach", a program of family planning interventions centered around jiggashas, community-based information and discussion centers. One aim, and apparent accomplishment, of the women's meetings has been to facilite husband/wife communication by emboldening women. Meetings of bari-heads and influential villagers have also been used to change men's attitudes towards family planning. Men are now forming their own jiggashas to discuss issues they see as important ${ }^{9}$. Save the Children's program in Nasirnagar Thana of Brahmanbaria District included family planning workshops conducted with traditional and religious leaders. Invitees were specifically drawn to represent those who matter in decision making at the local level (para level), those antagonistic towards family planning, and those who promote family planning. Most of the workshop participants were men. The evaluation of this project reports a 28.4 percent increase in the CAR due to these workshops. This would suggest that the meetings with these influential men facilitated the adoption of family planning in the area. Unfortunately, though it was originally intended that men be interviewed during the evaluation of the project (under the assumption that male workshop participants would mainly spread the message of family planning via other men), women were ultimately chosen as the survey respondents, apparently because men were not readily available for interview (Barkat et al., 1993). Thus, we don't have information on how the men, both the participants and the men they spoke to, were affected. It's hard to draw any conclusion other than that the program suggests that men can be effective motivators for family planning if their involvement is sought.

One other reference at an attempt to include men, if only for experimental purposes, was found. FHI and BIRPERT conducted a pilot study to determine if including husbands in the use of Norplant by counseling them about the method would improve the wife's continuation rate. This counseling consisted of presenting an informational brochure which men were given to take home. It gave information on the "method itself, its duration of effectiveness, its advantages and disadvantages, availability and follow-up requirements, as well as a discussion of the supportive role that husbands could play in the decision-making process and tolerance of side-effects." They find that the hazard for discontinuation among the acceptors in the husband-counseled group was 0.81 times the hazard for those in the husband-not-counseled group. This result was not significant at the $\mathrm{p}=.05$ level $(\mathrm{p}=.07)$. The conclusion that the counseling had an effect must be interpreted with caution, though, because of the possibility of selection bias. Women were self-selected into the husband-counseled group if they brought their husbands after being asked to do so.

\footnotetext{
9 see various information leaflets prepared by JHU/CCP.
} 


\section{CONCLUSION AND RECOMMENDATIONS}

The literature and survey data reviewed above leave little doubt that men in Bangladesh are suitable targets for family planning programs. The average man does not want more than two children and he does not want them spaced closely together. He is already well acquainted with all the modern methods of contraception and he approves of their use. Beyond this point, though, what we know about men and issues related to family planning grows murkier the need for basic research greater.

We don't know much about the value of children to men, including their attitudes towards sons versus daughters. Men profess to want small families, but if the first two children are girls, is this resolve weakened? As fertility levels in Bangladesh fall closer to replacement level, sex preferences will become an increasingly important determinant of natality rates, and men's roles in encouraging or discouraging favoritism should be understood.

There is a glaring absence of research on how men form opinions about family size, fertility and family planning, how they can be influenced, how they reach decisions on contraceptive use, and how they interact with their wives in this decision-making process. We need to know how men come to use or reject male methods, and we need to know the role they play in the choices their wives make. Regardless of the strength of the efforts made to encourage the use of male methods, the reality is that most of the available forms of contraception are female methods, and involving men in family planning will often mean facilitating conjugal communication and responsibility sharing. It is difficult to see how effective program strategies aimed at men can be designed without first studying both male and couple decision-making.

The literature raises several questions related to these issues. For instance, why do couples report different contraceptive use states and why do women say that their husbands disapprove of family planning when husbands say that they approve? Are couples simply not communicating, or is the answer more complicated, perhaps involving perceptions of what are socially acceptable attitudes for the women and men. While some couples are clearly acting jointly in family planning decision-making, others are not. What are the determinants of spousal communication and what are the results for contraceptive use? The pattern of female-dominated versus male-domiminated and joint decisions on first-time contraceptive use found in the Demographic and Health Survey raises interesting questions how decision-making changes as family planning becomes a more acceptable practice and how the balance of power between spouses varies over time, place and background characteristics.

It seems that concerted efforts to involve men in family planning have been few and far between up to this point in time. Those programs that do exist have not been evaluated such that conclusions about men are easy to draw, so there are few lessons to be learned about how to involve men in family planning. With so many basic research questions on men and family planning in Bangladesh remaining unanswered, though, it might be best to start there than attempting to design program interventions. Surveying the literature, it is striking how infrequently men have been surveyed, studied, or talked to. We do not know much about men because we have not asked, and it there that we should begin. 


\section{References}

Ahmed, Jahiruddin et al. 1992. Assessment of Clinical Contraception Services in the Bangladesh Family Planning Program. New York: AVSC.

Akhter, Halida Hanum and Saifuddin Ahmed. 1991. Determinants of Contraceptive Use Dynamics in Rural Bangladesh. Dhaka: Bangladesh Institute of Research for Promotion of Essential \& Reproductive Health and Technologies.

Amatya, R. et. al. 1994. "The effect of husband counseling on NORPLANT contraceptive acceptability in Bangladesh." Contraception 50: 263-273.

Aziz, K.M. Ashraful and Clarence Maloney. 1985. Life Stages, Gender and Fertility in Bangladesh. Dhaka: International Center for Diarrhoeal Disease Research, Bangladesh.

Barakat, Abul, Barakat-e-Khuda, and A.N.M. Sayeedul Haque Khan. 1993. A study on the impact of the workshop on family planning conducted with the traditional and religious leaders in Nasirnagar Thana by Save The Children (USA). Dhaka: University Research Corporation.

Bernhart, Michael and M. Mosleh Uddin. 1990. "Islam and Family Planning Acceptance in Bangladesh." Studies in Family Planning 21, 5: 287-292.

Chaudhury, R.H. 1978. "Married Women in Non-agricultural Occupations in a Metropolitan Urban Area of Bangladesh." Population Studies 32, 2: 261-273.

Cleland, John and W. Parker Mauldin. 1991. "The Promotion of Family Planning by Financial Payments: The Case of Bangladesh." Studies in Family Planning 22, 1: 1-18.

Davies, John. 1985. Oral Contraceptive Distribution in Bangladesh: Husbands as Providers and Instructors. Dissertation submitted the Graduate Division of the University of Hawaii.

Davies, John, S.N. Mitra, and William P. Schellstede. 1987. "Oral Contraception in Bangladesh: Social Marketing and the Importance of Husbands." Studies in Family Planning 18, 3: 157-168.

Finger, William R. 1992. "Getting More Men Involved." Network 13, 1: 4-6.

Folmar, Steven, S.M. Nurul Alam, and A.H.M. Raihan Sharif. 1992. Condom Use in Bangladesh: Final Report. Dhaka: Social Marketing Company.

Haider, Syed Jahangeer and M. Kabir. 1989. Male Attitudes Towards Vasectomy: A Review of Psychological Aspects. Dhaka: Association for Voluntary Surgical Contraceptive.

Hardee-Cleaveland, Karen. 1992. "Communication Key for Family Planning." Network 13, 1: 13.

Hasan, Yousuf, Rushikesh Maru, Ruth Simmons, and Ali Ashraf. 1992. Sterilization Trends and Policy Developments in Bangladesh. MCH-FP Extension Project Working Paper No. 72. Dhaka: International Center for Diarrhoeal Disease Research.

Islam, M.N. and M.N. Rahman. 1993. "Client satisfaction with sterilization procedure in Bangladesh." Asia-Pacific Population Journal 8, 1: 39-54. 
Karam, Robert. 1991. Seminar on the Dynamics of Condom Use Proceedings. Dhaka: Social Marketing Company.

Khan, A.R., I. Swenson, and A. Rahman. 1979. "A follow-up of vasectomy clients in rural Bangladesh." International Journal of Gynecology and Obstetrics 17, 1: 11-14.

Khan, Nasir Udin. 1993. Brand Awareness, Trial and Usage of Condoms. Findings presented at the Seminar on Dynamics of Condom Use in Bangladesh, Dhaka.

Khuda, Barakat. 1994. Method Mix in the Bangladesh Family Planning Program: Some Insights. Unpublished paper, Dhaka.

Kincaid, D.L., E. Massiah, and A.D. Gupta. 1993. Ideational Aspects of Fertility Change in Bangladesh. Paper prepared for the Annual Meeting of the Population Association of America, Cincinnati, Ohio April 1-3.

Mahmud, Simeen. 1988. "Exploring the Relationship between Women's Work and Fertility: The Bangladesh Context." The Bangladesh Development Studies Vol. XVI, 4: 99-113.

Mazumder, Mahbub Alam. 1993. Family planning from a male perspective in a Muslim society: a study in Chandpur, Bangladesh. Thesis prepared for Degree of Master of Science in Primary Health Care at The Flinders University of South Australia.

MacCauley et al. 1994. "Encouraging Men's Cooperation." Population Reports. Series M, No. 12. Baltimore, MD: Johns Hopkins School of Public Health, Population Information Program.

Mitra, Mira and S.N. Mitra. 1990. Followup Survey of Contraceptive Knowledge and Information Study 1990: Final Report. Dhaka: Mitra and Associates.

Mitra, S.N., Ann Larson, Gillian Foo and Shahidul Islam. 1990. Bangladesh Contraceptive Prevalence Survey - 1989. Dhaka: Mitra and Associates.

Mitra, S.N., M. Nawab Ali, Shahidul Islam, and Anne R. Cross. 1994. Bangladesh Demographic and Health Survey 1993-94 (draft). Dhaka: NIPORT, Mitra and Associates, and Macro International Inc.

National Steering Committee for Future Challenges in the FP-MCH Programme. 1994. Future Challenges in the FP-MCH Programme: A Plan For Action. Dhaka: Ministry of Health and Family Welfare, Government of Bangladesh.

Swenson, I. and A.R. Khan. 1982. "Demographic consequences, client satisfaction, and reasons for selecting sterilization among vasectomy and tubectomy clients in Bangladesh." Contraception 25 , 


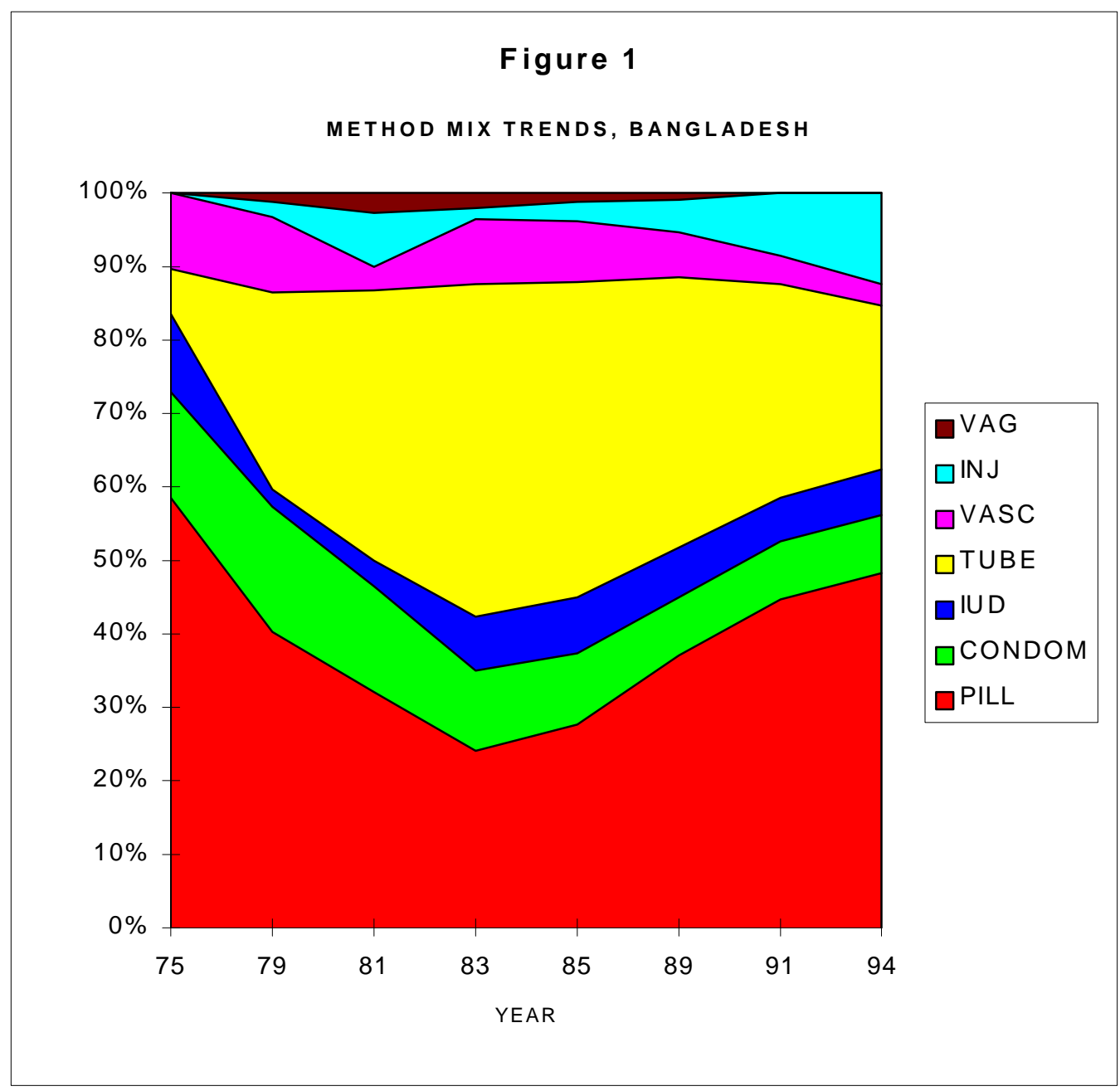

